Для цитирования: Литвяков Н.В., Ибрагимова М.К., Цыганов М.М., Дерюшева И.В., Певзнер А.М., Гарбуков Е.Ю., Дорошенко А.В., Слонимская Е.M. Ассоциация сочетания аберраций числа копий генов WNT-сигналинга и амплификаций генов стволовости в опухоли молочной железы с метастазированием. Сибирский онкологический журнал. 2020; 19(3): 78-88. - doi: 10.21294/1814-4861-2020-19-3-78-88.

For citation: Litviakov N.V., Ibragimova M.K., Tsyganov M.M., Deriusheva I.V., Pevsner A.M., Garbukov E.Yu., Doroshenko A.V., Slonimskaya E.M. Association of the combination of stemness gene amplifications and copy number aberrations of WNT-signaling genes in breast tumors with metastasis. Siberian Journal of Oncology. 2020; 19(3): 78-88. - doi: 10.21294/1814-4861-2020-19-3-78-88.

\title{
ASSOCIATION OF THE COMBINATION OF STEMNESS GENE AMPLIFICATIONS AND COPY NUMBER ABERRATIONS OF WNT-SIGNALING GENES IN BREAST TUMORS WITH METASTASIS
}

\author{
N.V. Litviakov ${ }^{1,2}$, M.K. Ibragimova ${ }^{1}$, M.M. Tsyganov' ${ }^{1}$ I.V. Deriusheva ${ }^{1}$, \\ A.M. Pevsner', E.Yu. Garbukov'1, A.V. Doroshenko', E.M. Slonimskaya³
}

Cancer Research Institute, Tomsk National Research Medical Center, Russian Academy of Sciences, Tomsk, Russia ${ }^{1}$

5, Kooperativny Street, 634050-Tomsk, Russia. E-mail: nvlitv72@yandex.ru¹

National Research Tomsk State University, Tomsk, Russia ${ }^{2}$

36, Lenin Ave., 634050-Tomsk, Russia²

Saint-Petersburg State University, Saint-Petersburg, Russia ${ }^{3}$

13B, Universitetskaya Emb., St Petersburg-199034, Russia ${ }^{3}$

\section{Abstract}

We studied the association between the presence of 2 or more stemness gene amplifications as well as copy number aberrations (CNAs) of WNT signaling genes in residual breast tumor and metastasis. WNT pathway genes associated with metastasis were identified. Material and Methods. The study included 30 patients with breast cancer, who had 2 or more stemness gene amplifications in the residual tumor after neoadjuvant chemotherapy. Fifteen of the thirty patients developed hematogenous metastases; they constituted a group with metastases, the remaining 15 patients entered the second group without metastases. The tumor DNA was examined using a CytoScanHD Array microarray (Affymetrix, USA). Results. By subtracting amplification and deletion frequencies in 852 cytobands between groups with metastases and without metastases, 21 cytobands were identified with the largest difference in deletion and amplification frequencies. They contain 19/150 of WNT genes (12 activators: SKP1, WNT8A, MAPK9, CCND3, FZD9, WNT8B, CCND1, PLCB2, $P R K C B, F Z D 2, W N T 3, W N T 9 B$ and 7 negative regulators: GSK3B, APC, CSNK2B, SFRP5, BTRC, TCF7L2, CSNK2A2). A point system was developed: when amplifying WNT-signaling activators or deletion of negative regulators, one point was added to the total score, and vice versa when deleting WNT-signaling activators or amplification of negative regulators, one point was taken from the total amount. It was shown that $93 \%$ $(14 / 15)$ of patients with metastases had a total score higher than 0 , while $93 \%(14 / 15)$ of patients without metastases had a total score of zero or less than zero. The differences between the groups were statistically significant according to the two-sided Fisher test with a high level of confidence probability $(p=0.000003)$ and the log-rank test $(p=0.00004)$ when assessing non-metastatic survival by the Kaplan-Mayer method. Conclusion Nineteen WNT signaling genes were identified. Copy number aberrations of these genes in combination with stemness gene amplifications in residual tumors were associated with metastasis. A new highly effective prognostic factor for breast cancer was identified.

Key words: breast cancer, WNT-pathway, metastasis, copy number aberration, residual tumor. 


\title{
АССОЦИАЦИЯ СОЧЕТАНИЯ АБЕРРАЦИЙ ЧИСЛА КОПИЙ ГЕНОВ WNТ-СИГНАЛИНГА И АМПЛИФИКАЦИЙ ГЕНОВ СТВОЛОВОСТИ В ОПУХОЛИ МОЛОЧНОЙ ЖЕЛЕЗЫ С МЕТАСТАЗИРОВАНИЕМ
}

\author{
Н.В. Литвяков ${ }^{1,2}$, М.К. Ибрагимова ${ }^{1}$, М.М. Цыганов ${ }^{1}$, И.В. Дерюшева ${ }^{1}$, \\ А.М. Певзнер ${ }^{1}$, Е.Ю. Гарбуков ${ }^{1}$, А.В. Дорошенко1, Е.М. Слонимская ${ }^{3}$
}

\begin{abstract}
Научно-исследовательский институт онкологии, Томский национальный исследовательский медицинский центр Российской академии наук, г. Томск, Россия 1

Россия, 634050, г. Томск, пер. Кооперативный, 5. E-mail: nvlitv72@yandex.ru

Национальный исследовательский Томский государственный университет, г. Томск, Россия²

Россия, 634050, Томск, пр. Ленина, $36^{2}$

Санкт-Петербургский государственный университет, г. Санкт-Петербург, Россия 3

Россия, 199034, г. Санкт-Петербург, Университетская набережная, 7-9³
\end{abstract}

\section{Аннотация}

\begin{abstract}
Введение. Изучена ассоциация с гематогенным метастазированием наличия 2 и более амплификаций генов стволовости и CNA (Copy Number Aberration) локусов генов WNT-сигнального пути в остаточной резидуальной опухоли молочной железы. Идентифицированы гены WNT-pathway, ассоциированные с метастазированием. Материал и методы. В исследование были включены 30 больных раком молочной железы, в резидуальной опухоли которых после неоадъювантной химиотерапии были 2 и более амплификации генов стволовости. У 15 из 30 больных развились гематогенные метастазы, они составили группу с метастазами, во вторую группу без метастазов вошли остальные 15 пациентов. ДНК опухоли была исследована при помощи микроматрицы CytoScanHD Array (Affymetrix, USA). Peзультаты. Путем вычитания частот амплификаций и делеций по 852 цитобендам между группами с метастазами и без метастазов был установлен 21 цитобенд с наибольшей разницей частот делеций и амплификаций. В них находятся 19 из 150 генов WNT (14 активаторов: SKP1, WNT8A, MAPK9, CCND3, FZD9, WNT8B, CCND1, PLCB2, PRKCB, FZD2, WNT3, WNT9B и 7 негативных регуляторов: GSK3B, $A P C, C S N K 2 B, S F R P 5, B T R C, T C F 7 L 2, C S N K 2 A 2)$. Была разработана балльная система, при амплифрикации активаторов WNT-сигналинга или делеции негативных регуляторов к общей сумме баллов прибавлялся один балл, и, наоборот, при делеции активаторов WNT-сигналинга или амплификации негативных регуляторов от общей суммы отнимался один балл. Показано, что 93 \% (14/15) больных с метастазами имеют суммарный балл больше 0, в то время как 93 \% (14/15) больных без метастазов имеют суммарный балл, равный нулю или меньше нуля. Различия между группами статистически значимы по двустороннему критерию Фишера с высоким уровнем доверительной вероятности $(p=0,000003)$ и по лог-ранговому тесту $(p=0,00004)$ при оценке безметастатической выживаемости по методу Каплана - Майера. Заключение. Были идентифицированы 19 генов WNT-сигналинга, CNA которых в резидуальной опухоли, совместно с амплификациями генов стволовости ассоциированы с метастазированием и могут использоваться в качестве прогностического фактора.
\end{abstract}

Ключевые слова: рак молочной железы, WNT-сигналинг, метастазирование, аберрация числа копий, остаточная опухоль.

\section{Introduction}

Previously, we showed the association of amplifications of chromosome regions of stemness genes localization (3q (26.33), 5p (15.33; 13.1), 6p $(24.3 ; 22.3 ; 21.33 ; 21.32), 7 \mathrm{q}(11.23 ; 21.13 ; 31.2$; $32.1), 8 \mathrm{q}(11.21 ; 24), 9 \mathrm{p}(21.2), 9 \mathrm{q}(34.3 ; 21.13 ; 31.2$, $22.33), 10 \mathrm{p}(15.2 ; 13 ; 12.2 ; 11.22), 10 \mathrm{q} 22.1,12 \mathrm{p}$ (13.31) 13q (34; 32.3; 22.1; 13.3; 12.2), 16p (11.2; 13.3), 18q (21.1; 21.2) 19p (13.3; 13.2; 13.12) with hematogenous metastasis. It was found that in cases when tumor cell clones with 2 or more amplifications of the above chromosomal regions remained in a residual tumor after neoadjuvant chemotherapy, $50 \%$ of the patients developed metastases. When all amplifications were eliminated or only one amplification remained,
$100 \%$ of patients did not develop metastases [1]. The results of this study showed that the presence of 2 or more amplifications at regions of stemness gene localization in residual tumors was a necessary, but not sufficient condition for metastasis development. There are some other genetic changes that, along with amplification of stemness genes, are necessary and sufficient for development of metastases after presurgery chemotherapy.

Milanovic et al. (2018) reported that replicative aging of breast tumor cells occurred after treatment with doxorubicin and tamoxifen. After cancellation of doxorubicin and tamoxifen, the activity of the WNT signaling pathway significantly increased in tumor cells and the number of stem tumor cells increased 
sharply. Tumor growth became even more active than it was before chemo- and hormone therapy [2]. It remains unknown why in some cases WNT signaling pathways are activated, while in other cases they are not activated and some tumors do not progress.

Our working hypothesis is that activation of WNT signaling pathway in tumor cells is due to the presence of copy number aberration (CNA) of WNT signaling pathway genes. We believe that a tumor emerges from replicative aging caused by NAC and metastasizes if there are 2 or more amplifications of stemness genes (a necessary condition) and CNA genes of WNT signaling pathway. If there are only amplifications of stemness genes or CNA genes of WNT signaling pathway, a tumor does not metastasize.

In addition to emerging from replicative aging, WNT can directly induce stemness genes, thereby providing a significant increase in the number of tumor stem cells and the likelihood of metastasis. Some authors have shown that MYC, which is one of the stemness genes and is part of the Yamanaki cocktail, is directly connected to WNT signaling pathway and when WNT is attached to Frizzled receptors, expression of markers of epithelial-mesenchymal transition and stemness of SNAI2, MYC and others is activated. Canonical WNT signaling caused by LRP6 Cyclin Y/CDK14 priming helps stabilize $\beta$-catenin-independent proteins, block polyphosphorylation and polyubiquitination of target proteins, including c-Myc $[3,4]$. Activation of $\beta$-catenin in WNT signaling pathway also stimulates hyperexpression of MYC [5].

In accordance with the working hypothesis, we identified WNT pathway genes, whose CNA together with the amplification of stemness genes, were associated with metastasis.

\section{Material and Methods}

Between 2009 and 2014, 30 patients with IIbIIIa (T2-3N0-1M0) luminal B breast cancer were treated at Cancer Research Institute of Tomsk NRMC (Tomsk, Russia). The age of the patients ranged from 35 to 62 years (average age $52.4 \pm 0.5$ ) All procedures followed were in accordance with the Helsinki Declaration (1964, amended in 1975 and 1983). This study was approved by the institutional review board, and all patients signed an informed consent for voluntary participation (tabl. 1). All patients received 6 to 8 cycles of systemic neoadjuvant chemotherapy with the AC (Adriamycin, and Cyclophosphamide) or AT/ACT (Adriamycin and Taxotere or Adriamycin, Cyclophosphamide and Taxotere), or Taxotere. Clinical and imaging responses were categorized according to WHO and International Union Against Cancer criteria [7]. A partial response (PR) was determined as a tumor reduction $>50 \%$ and stable disease (SD) as a tumor reduction $<50 \%$ or a tumor size increase of $<25 \%$ and progressive disease (PD) as a tumor size increase of $>25 \%$. Physical examination was performed before NAC and before surgery to determine the clinical response. Surgery (radical resection, sectoral resection or mastectomy) was performed within three to four weeks after the last administration of chemotherapy in responsive patients. After surgery hormonal therapy was given.

DNA was extracted from fresh samples of postNAC residual tumor tissues using the QIAamp DNA mini Kit (Qiagen, Germany \#51304).

Microarray analysis. To study CNAs of breast tumor, microarray analysis was performed using high density microarray platform Affymetrix (USA) CytoScan ${ }^{\mathrm{TM}}$ HD Array, (http://www.affymetrix.com/ esearch/search.jsp?pd= prod520004\&N=4294967292). Procedures of sample preparation, hybridization and scanning were performed in accordance with the manufacturer's protocol using the system Affymetrix GeneChip ${ }^{\circledR}$ Scanner 30007 G (Affymetrix, USA). The Chromosome Analysis Suite 4.0 software (Affymetrix, USA), which was specifically devised for analyzing microarray results from the CytoScan ${ }^{\mathrm{TM}} \mathrm{HD}$ Array, was used. Unbalanced chromosomal aberrations (deletions and amplifications, or Loss and Gain) were detected in all chromosomal regions.

Bioinformatics Methods. For each of 852 cytobands of patient groups with 2 or more amplifications of stemness genes with metastases and without metastases, the frequency of amplifications and deletions was determined and a histogram was constructed for each group. Afterwards, these histograms were combined. Thus, cytobands were calculated with the greatest difference in amplification and deletion frequencies. These data are shown in Figure 1. Using the KEGG GSEA database (http://software.broadinstitute.org/ gsea/msigdb/cards/KEGG_WNT_SIGNALING_ PATHWA), 150 human WNT signaling genes were selected which are presented in Table 2 . Using the GeneCards database (https://www.genecards.org/) the localization of each gene was determined. We found genes that were localized in cytobands with the highest frequency of amplifications and deletions according to the data presented in Fig. 1. These genes are highlighted in table 2 in different colors. At the next stage, each of the selected genes was annotated using several databases: Reactome (https://reactome.org), UniPlot (https://www.uniprot.org), GeneCards (https:// www.genecards.org/), OMIM (https://omim.org/), Wnt signaling pathway Gene Ontology Term (http:// www.informatics.jax.org/vocab/gene_ontology/ GO:0016055), KEGG PATHWAY: Wnt signaling pathway - Homo sapiens (human) (https://www. genome.jp/kegg/pathway/hsa/hsa 04310.html) and the role of the gene in the regulation of WNT-pathway was determined. Also, articles were used for annotation.

Statistical analysis. A two-sided $p$-value was calculated using Fisher's exact test http://vassarstats. net/odds2x2.html. Metastasis-free survival was calculated using the Kaplan-Meier method, and differences among patient groups were evaluated using the log-rank test. 


\section{Results}

By subtracting the frequencies of cytoband amplifications and deletions in residual tumors of patients with 2 or more amplifications of stemness genes between groups with metastases (patients B1, G1, D1, E1, K1, K2, K7, L1, R1, S1, S2, S3, Ch1, Ch3, Yu1) and without metastases (patients D3, J1, J2, K6, L2, L3, M4, N1, P1, P3, P2, S7, S10, Ch2,

\section{Клинико-патологические параметры больных раком молочной железы и амплификации генов стволовости в остаточной резидуальной опухоли}

The clinicopathological parameters of breast cancer patients and stemness gene amplifications in residual tumors

\begin{tabular}{|c|c|c|c|c|c|c|c|}
\hline $\begin{array}{l}\text { Пациенты/ } \\
\text { Patients }\end{array}$ & $\begin{array}{c}\text { Амплификации локусов генов ство- } \\
\text { ловости в резидуальной опухоли/ } \\
\text { Stemness genes loci amplifications in } \\
\text { residual tumor }\end{array}$ & $\mathrm{T}$ & $\mathrm{N}$ & $\begin{array}{c}\text { Отве } \\
\text { NA } \\
\%\end{array}$ & $\begin{array}{l}\text { HAXT/ } \\
\text { sponse } \\
\text { По BO3/ } \\
\text { WHO }\end{array}$ & $\begin{array}{c}\text { Метастазы/ } \\
\text { Metastasis }\end{array}$ & $\begin{array}{c}\text { Безметастатическая } \\
\text { выживаемость, мес/ } \\
\text { Metastasis-free survival, } \\
\text { month }\end{array}$ \\
\hline B1 & $5 \mathrm{p} 16 \mathrm{p}$ & 2 & 1 & 74 & PR & Да/Yes & 25 \\
\hline G1 & $3 q 5 p 8 q$ & 2 & 0 & 7 & $\mathrm{SD}$ & Да/Yes & 62 \\
\hline D1 & $5 \mathrm{p} 8 \mathrm{q} 9 \mathrm{q} 10 \mathrm{q}$ & 2 & 1 & 86 & PR & Да/Yes & 19 \\
\hline E1 & $3 q 16 p 18 q$ & 2 & 2 & -66 & PD & Да/Yes & 47 \\
\hline $\mathrm{K} 1$ & $7 q 8 q$ & 2 & 1 & 75 & PR & Да/Yes & 28 \\
\hline $\mathrm{K} 2$ & $8 \mathrm{q} 12 \mathrm{p} 16 \mathrm{p}$ & 2 & 0 & 0 & SD & Да/Yes & 105 \\
\hline K7 & $3 q 6 p 8 q 9 q 13 q$ & 2 & 1 & 80 & PR & Да/Yes & 12 \\
\hline $\mathrm{L} 1$ & $5 p 8 q 10 p$ & 2 & 3 & 28 & SD & Да/Yes & 10 \\
\hline $\mathrm{R} 1$ & $5 \mathrm{p} 7 \mathrm{q} 9 \mathrm{p} 10 \mathrm{p}$ & 3 & 2 & 21 & $\mathrm{SD}$ & Да/Yes & 12 \\
\hline S1 & $5 \mathrm{p} 7 \mathrm{q} 16 \mathrm{p} 18 \mathrm{q} 19 \mathrm{p}$ & 2 & 2 & 45 & SD & Да/Yes & 11 \\
\hline S2 & $5 \mathrm{p} 6 \mathrm{p} 8 \mathrm{q} 9 \mathrm{p} 10 \mathrm{p} 18 \mathrm{q} 19 \mathrm{p}$ & 2 & 1 & -5 & SD & Да/Yes & 20 \\
\hline S3 & $5 p 6 p 7 q 8 q 13 q 19 p$ & 3 & 3 & -35 & PD & Да/Yes & 17 \\
\hline Ch1 & $5 \mathrm{p} 7 \mathrm{q} 10 \mathrm{q} 8 \mathrm{q} 16 \mathrm{p}$ & 2 & 0 & 42 & SD & Да/Yes & 23 \\
\hline $\mathrm{Ch} 3$ & $5 p 8 q 16 p 19 p$ & 3 & 3 & 60 & PR & Да/Yes & 21 \\
\hline Yu1 & $6 p 8 q 13 q$ & 2 & 3 & 59 & PR & Да/Yes & 43 \\
\hline D3 & $5 p 8 q$ & 2 & 1 & 35 & SD & Het/No & 24 \\
\hline $\mathrm{J} 1$ & $8 q 16 p$ & 4 & 0 & 75 & PR & Нет/No & 115 \\
\hline $\mathrm{J} 2$ & $8 \mathrm{q} 16 \mathrm{p} 19 \mathrm{p}$ & 2 & 1 & 0 & SD & Heт/No & 26 \\
\hline K6 & $3 q 8 q$ & 2 & 1 & 36 & SD & Нет/No & 12 \\
\hline L2 & $5 p 8 q$ & 2 & 0 & 58 & PR & Нет/No & 56 \\
\hline L3 & $8 q 13 q 16 p$ & 2 & 0 & 60 & PR & Нет/No & 30 \\
\hline M4 & $3 q 8 q$ & 2 & 0 & 76 & PR & Нет/No & 48 \\
\hline N1 & $6 \mathrm{p} 7 \mathrm{q} 8 \mathrm{q} 10 \mathrm{p} 10 \mathrm{q} 16 \mathrm{p}$ & 2 & 2 & 57 & PR & Нет/No & 32 \\
\hline $\mathrm{P} 1$ & $6 \mathrm{p} 7 \mathrm{q} 8 \mathrm{q} 9 \mathrm{p}$ & 4 & 1 & 67 & PR & Нет/No & 63 \\
\hline P3 & $3 q 8 q$ & 2 & 1 & 65 & PR & Нет/No & 13 \\
\hline $\mathrm{P} 2$ & $6 \mathrm{p} 8 \mathrm{q} 18 \mathrm{q}$ & 2 & 0 & 55 & PR & Heт/No & 31 \\
\hline S7 & $8 \mathrm{q} 10 \mathrm{p}$ & 2 & 1 & 55 & PR & Нет/No & 96 \\
\hline S10 & $5 \mathrm{p} 6 \mathrm{p} 8 \mathrm{q} 10 \mathrm{p}$ & 2 & 0 & 67 & PR & Нет/No & 12 \\
\hline $\mathrm{Ch} 2$ & $5 \mathrm{p} 7 \mathrm{q} 8 \mathrm{q} 10 \mathrm{p} 16 \mathrm{p}$ & 2 & 0 & 49 & SD & Heт/No & 41 \\
\hline Sh1 & $3 q 7 q 18 q$ & 2 & 0 & 71 & PR & Нет/No & 89 \\
\hline
\end{tabular}

Примечание: PR - частичная регрессия, SD - стабилизация, PD - прогрессирование; все пациентки имели люминальный В молекулярный подтип PMЖ. Люминальный В подтип определялся как позитивный по ER и PR статусу и Ki67> 30 \%. ER+ экспрессия экстрогеновых рецепторов больше 0, PR+ экспрессия прогестероновых рецепторов больше 0. HER2 тестировали в соответствии с рекомендациями Атегіcan Society of Clinical Oncology/College of American Pathologists Guideline 2007 Recommendation [6].

Note: PR - partial response, SD - stable disease, PD - progressive disease; All patients had a luminal B subtype. Luminal B subtype was determined when positive ER and PR status and Ki67 > $30 \%$ were observed. ER+ expression of estrogen receptors more than 0 , PR+ expression of progesterone receptors more than 0. HER2 testing is performed in accordance with American Society of Clinical Oncology/College of American Pathologists Guideline 2007 Recommendation [6]. 
Таблица 2/Table 2

Гены WNT-сигналинга: их локализация, наличие высокой разности в частоте CNA в одной из групп с метастазами или без метастазов и функция в WNT-сигналинге

WNT-signaling genes: their localization, presence of a big difference in CNA frequency in one of the groups with or without metastases and function in WNT-signaling

\begin{tabular}{|c|c|c|c|c|}
\hline $\begin{array}{l}\text { Гены/ } \\
\text { Genes }\end{array}$ & $\begin{array}{l}\text { Локализация/ } \\
\text { Cytoband }\end{array}$ & $\begin{array}{c}\text { Наличие } \\
\text { метастазов/ } \\
\text { Yes metastasis }\end{array}$ & $\begin{array}{c}\text { Отсутствие } \\
\text { матастазов/ } \\
\text { No metastasis }\end{array}$ & Функция/Function \\
\hline GSK3B & $3 q 13.33$ & Del 13\% & Amp 33\% & $\begin{array}{l}\text { Один из ключевых негативных регуляторов канонического } \\
\text { WNT-пути/ } \\
\text { One of the key negative regulators of canonical WNT-pathway }\end{array}$ \\
\hline$A P C$ & $5 \mathrm{q} 22.2$ & Amp $20 \%$ & Del 33\% & $\begin{array}{l}\text { Негативный регулятор канонического WNT-пути/ } \\
\text { Negative regulator of canonical WNT-pathway }\end{array}$ \\
\hline$P P P 2 C A$ & $5 \mathrm{q} 31.1$ & Amp $20 \%$ & Del $20 \%$ & $\begin{array}{l}\text { Позитивный регулятор канонического WNT-пути/ } \\
\text { Positive regulator of WNT-pathway }\end{array}$ \\
\hline SKP1 & $5 \mathrm{q} 31.1$ & Amp 20\% & Del $20 \%$ & $\begin{array}{l}\text { Участвует в трансдукции сигнала WNT-пути, активатор/ } \\
\text { Participates in WNT-pathway signal transduction, activator }\end{array}$ \\
\hline$T C F 7$ & $5 \mathrm{q} 31.1$ & Amp 20\% & Del $20 \%$ & $\begin{array}{l}\text { Негативный регулятор канонического WNT-пути/ } \\
\text { Negative regulator of apoptosis through WNT-pathway }\end{array}$ \\
\hline WNT8A & $5 \mathrm{q} 31.2$ & Amp 20\% & Del $20 \%$ & Активатор WNT-пути/WNT-pathway activator \\
\hline MAPK9 & $5 \mathrm{q} 35.3$ & Amp 20\% & Del $0 \%$ & $\begin{array}{l}\text { Участвует в трансдукции сигнала WNT-пути, активатор/ } \\
\text { Participates in WNT-pathway signal transduction, activator }\end{array}$ \\
\hline$C S N K 2 B$ & $6 \mathrm{p} 21.33$ & Del $0 \%$ & Amp 20\% & Активатор ТР53/Activator of ТР53 \\
\hline PPARD & $6 \mathrm{p} 21.31$ & Del $0 \%$ & Amp 20\% & $\begin{array}{l}\text { Позитивный регулятор канонического WNT-пути/ } \\
\text { Positive regulator of WNT-pathway }\end{array}$ \\
\hline$P P P 2 R 5 D$ & $6 \mathrm{p} 21.1$ & Amp 0\% & Del $27 \%$ & $\begin{array}{l}\text { Позитивный регулятор канонического WNT-пути/ } \\
\text { Positive regulator of WNT-pathway }\end{array}$ \\
\hline CCND3 & $6 \mathrm{p} 21.1$ & Amp $0 \%$ & Del $27 \%$ & $\begin{array}{l}\text { Активация пролиферации через WNT-путь/ } \\
\text { Activation of proliferation via WNT-pathway }\end{array}$ \\
\hline FZD9 & $7 \mathrm{q} 11.23$ & Amp $20 \%$ & Del $0 \%$ & Активатор WNT-пути/WNT-pathway activator \\
\hline$C U L 1$ & $7 \mathrm{q} 36.1$ & Amp 20\% & Del 0\% & $\begin{array}{l}\text { Позитивный регулятор канонического WNT-пути/ } \\
\text { Positive regulator of WNT-pathway }\end{array}$ \\
\hline FRAT1 & $10 \mathrm{q} 24.1$ & Del $27 \%$ & Amp 7\% & $\begin{array}{l}\text { Позитивный регулятор канонического WNT-пути/ } \\
\text { Positive regulator of WNT-pathway }\end{array}$ \\
\hline FRAT2 & $10 \mathrm{q} 24.1$ & Del $27 \%$ & Amp 7\% & $\begin{array}{l}\text { Позитивный регулятор канонического WNT-пути/ } \\
\text { Positive regulator of WNT-pathway }\end{array}$ \\
\hline SFRP5 & $10 \mathrm{q} 24.2$ & Del $27 \%$ & Amp 0\% & $\begin{array}{l}\text { Негативный регулятор канонического WNT-пути/ } \\
\text { Negative regulator of canonical WNT-pathway }\end{array}$ \\
\hline$W N T 8 B$ & $10 \mathrm{q} 24.31$ & Del $27 \%$ & Amp 7\% & Активатор WNT-пути/WNT-pathway activator \\
\hline$B T R C$ & $10 \mathrm{q} 24.32$ & Del $27 \%$ & Amp 7\% & $\begin{array}{l}\text { Негативный регулятор канонического WNT-пути/ } \\
\text { Negative regulator of canonical WNT-pathway }\end{array}$ \\
\hline$T C F 7 L 2$ & $10 \mathrm{q} 25.2-\mathrm{q} 25.3$ & Del $27 \%$ & Amp 0\% & $\begin{array}{l}\text { Негативный регулятор канонического WNT-пути/ } \\
\text { Negative regulator of canonical WNT-pathway }\end{array}$ \\
\hline$C C N D 1$ & $11 \mathrm{q} 13.3$ & $\begin{array}{l}\text { Amp 33\% } \\
\text { Del 7\% }\end{array}$ & Del $0 \%$ & $\begin{array}{l}\text { Активация пролиферации через WNT-путь/ } \\
\text { Activation of proliferation via WNT-pathway }\end{array}$ \\
\hline CHP1 & $15 \mathrm{q} 15.1$ & Amp 7\% & Del 33\% & $\begin{array}{l}\text { Ингибитор NFAT неканонического WNT-пути/ } \\
\text { NFAT inhibitor of noncanonical WNT-pathway }\end{array}$ \\
\hline$P L C B 2$ & $15 q 15.1$ & Amp 7\% & Del 33\% & Активатор WNT-пути/WNT-pathway activator \\
\hline$C S N K 2 A 2$ & $16 \mathrm{q} 21$ & Del $27 \%$ & Amp 7\% & Активатор ТР53/Activator of ТР53 \\
\hline$P R K C B$ & $16 \mathrm{p} 12.2-\mathrm{p} 12.1$ & $\begin{array}{l}\text { Amp } 20 \% \\
\text { Del } 7 \%\end{array}$ & Del $0 \%$ & Активатор WNT-пути/WNT-pathway activator \\
\hline FZD2 & $17 \mathrm{q} 21.31$ & Amp 27\% & Del $27 \%$ & Активатор WNT-пути/WNT-pathway activator \\
\hline WNT3 & $17 \mathrm{q} 21.31-\mathrm{q} 21.32$ & Amp 27\% & Del $20 \%$ & Активатор WNT-пути/WNT-pathway activator \\
\hline WNT9B & $17 \mathrm{q} 21.32$ & Amp 27\% & Del $20 \%$ & Активатор WNT-пути/WNT-pathway activator \\
\hline
\end{tabular}


WNT2B 1p13.2, VANGL1 1p13.1, DVL1 1p36.33, CACYBP 1q25.1, JUN 1p32.1, WNT4 1p36.12, PPP2R5A 1q32.3, PRKACB 1p31.1, CTNNBIP1, 1p36.22, VANGL2 1q23.2, WNT9A 1q42.13, WNT3A 1q42.13, PPP3R1 2p14, WNT6 2q35, FZD5 2q33.3, WNT10A 2q35, FZD7 2q33.1, TCF7L1 2p11.2, ROCK2 2p25.1, CTNNB1 3p22.1, PRICKLE2 3p14.1, DVL3 3q27.1, RHOA 3p21.31, SENP2 3q27.2, WNT5A 3p14.3, WNT7A 3p25.1, RUVBL1 3q21.3, TBL1XR1 3q26.32, CTBP1 4p16.3, DKK2 4q25, LEF1 4q25, PPP3CA 4q24, MAPK10 4q21.3, SFRP2 4q31.3, CXXC4 4q24, CAMK2D 4q26, CSNK1A1 5q32, CAMK2A 5q32, FBXW11 5q35.1, NKD2 5p15.33, DAAM2 6p21.2, MAP3K7 6q15, WNT16 7q31.31, RAC1 7p22.1, SFRP4 7p14.1, WNT2 7q31.2, CAMK2B 7p13, FZD1 7q21.13, DKK4 8p11.21, MYC 8q24.21, PPP2CB 8p12, PPP3CC 8p21.3, SFRP1 8p11.21, SOX17 8q11.23, FZD3 8p21.1, FZD6 8q22.3, PPP3R2 9q31.1, PRKACG 9q21.11, CER1 9p22.3, CTBP2 10q26.13, PPP3CB 10q22.2, MAPK8 10q11.22, CAMK2G 10q22.2, FZD8 10p11.21, LRP5 11q13.2, MMP7 11q22.2, PLCB3 11q13.1, PPP2R1B 11q23.1, PPP2R5B 11q13.1, CCND1 11q13.3, WNT11 11q13.5, FOSL1 11q13.1, FZD4 11q14.2, WIF1 12q14.3, FZD10 12q24.33, PRICKLE1 12q12, LRP6 12p13.2, SKP1P2 12p12.3, WNT1 12q13.12, WNT10B 12q13.12, WNT5B 12p13.33, CCND2 12p13.32, CSNK1A1L 13q13.3, DAAM1 14q23.1, NFATC4 14q12, PPP2R5C 14q32.31, PPP2R5E 14q23.2, PSEN1 14q24.2, CHD8 14q11.2, SMAD3 15q22.33, NFAT5 16q22.1, CREBBP 16p13.3, NFATC3 16q22.1, CHP2 16p12.2, SIAH1 16q12.1, AXIN1 16p13.3, NKD1 16q12.1, DVL2 17p13.1, NLK 17q11.2, PRKCA 17q24.2, RAC3 17q25.3, TP53 17p13.1, AXIN2 17q24.1, SMAD2 18q21.1, SMAD4, 18q21.2, NFATC1 18q23, ROCK1 18q11.1, APC2 19p13.3, PPP2R1A 19q13.41, PRKACA 19p13.1, PRKCG 19q13.42, CSNK2A1 20p13, PLCB1 20p12.3, NFATC2 20q13.2, PLCB4 20p12.3-p12.2, CSNK1E 22q13.1, EP300 22q13.2, RAC2 22q13.1, WNT7B 22q13.31, RBX1 22q13.2, PORCN Xp11.23, PRKXXp22.33, TBL1XXp22.31-p22.2, TBL1Y Yp11.2

Примечание: гены, для которых не была показана высокая разница в частотах CNA, собраны внизу таблицы. Зеленым цветом выделены негативные регуляторы WNT-pathway, красным цветом - позитивные регуляторы WNT-pathway, лиловым цветом - активаторы WNT-раthwау и темно-синим - нейтральные факторы.

Note: genes for which a big difference in CNA frequencies was not shown are presented at the bottom of the table. Negative WNT-pathway regulators are highlighted in green, WNT-pathway positive regulators are red, WNT-pathway activators are lilac, and WNT-pathway neutral factors are dark blue.

Sh1) chromosomal regions were detected with the highest difference in the frequencies of deletions and amplifications. Graphically, this is shown in Figure 1 , which superimposes deletion and amplification frequencies of these two groups of patients. 21 cytobands (3q13.33, 5q22.2, 5q31.1, 5q31.2, 5q35.3, 6p21.33, 6p21.31, 6p21.1, 7q11.23, 7q36.1, 10q24.1, $10 \mathrm{q} 24.2,10 \mathrm{q} 24.31,10 \mathrm{q} 24.32,10 \mathrm{q} 25.2,11 \mathrm{q} 13.3$, $15 \mathrm{q} 15.1,16 \mathrm{q} 21,16 \mathrm{p} 12.2-\mathrm{p} 12.1,17 \mathrm{q} 21.31,17 \mathrm{q} 21.32)$ were identified with the greatest difference in the frequency of deletions and amplifications between groups of patients with metastases and without metastases (fig. 1, tabl. 2). The first top 3 genes were taken based on the difference in CNA frequencies between the groups with metastasis and without metastasis. For amplifications these were 33, 27 and $29 \%$; for deletions $-27,33$ and $40 \%$.

Table 2 also lists all 150 genes of human WNT signaling in accordance with http://software. broadinstitute.org/gsea/msigdb/cards/KEGG_WNT SIGNALING_PATHWAY and their chromosome localization, as well as genes with the top 3 differences in deletion and/or amplification frequencies between groups of patients with metastases and without metastases, and the function of these genes.

In total, in the chromosomal regions with the largest difference in deletion and amplification frequencies, 27 WNT signaling genes were localized: $G S K 3 B, A P C$, PPP2CA, SKP1, TCF7, WNT8A, MAPK9, CSNK2B, PPARD, PPP2R5D, CCND3, FZD9, CUL1, FRAT1, FRAT2, SFRP5, WNT8B, BTRC, TCF7L2, CCND1, CHP1, PLCB2, CSNK2A2, PRKCB, FZD2, WNT3, WNT9B (tabl. 2).

We divided all identified WNT-signaling genes into three large groups. The first group included activators of WNT-signaling (lilac); it was composed of receptor genes of the WNT signal pathway, receptor ligands, secondary messengers and transcription factors that play a key role in the work of the WNT-pathway. Also, this group included two cyclins D3 and D1, which trigger the cell cycle via WNT-signaling and are the endpoint of the WNT signaling pathway. In total, this group included 12 genes: SKP1, WNT8A, MAPK9, CCND3, FZD9, WNT8B, CCND1, PLCB2, PRKCB, FZD2, WNT3, WNT9B. Activation of WNT signaling should be substantially facilitated by amplification of chromosomal regions of localization of these genes and substantially hindered by deletions. The second group of genes included genes whose products, according to OMIM and GeneCards, negatively regulate the WNT signaling pathway (green). This group included 7 genes: GSK3B, APC, CSNK2B, SFRP 5, BTRC, TCF7L2, CSNK2A2. Activation of WNT signaling should be significantly facilitated by deletions of chromosomal regions of these genes localization and significantly hindered by their amplifications. The third group was composed of positive regulators of canonical and noncanonical WNT signaling pathways (PPP2CA, TCF7, PPARD, PPP2R5D, CUL1, CHP1, FRAT1, FRAT2). It included some transcription factors, secondary messengers, kinases. They can exert a noticeable but not as critical effect as activators on the WNT-signaling pathway, while the activity of the products of these genes can either be suppressed by other factors, or they belong to the noncanonical pathway, or they regulate the manifestations of WNT signaling little associated with proliferation, migration, adhesion and stemming, i.e. those mechanisms that are necessary for metastasis. CNA regions of localization of these genes were excluded from further analysis due to the high pleiotropy of mutual influences and low significance for metastasis mechanisms. CHP 1 belong to the noncanonical WNT-signaling pathway. 
After such preliminary bioinformatics selection of WNT-signaling genes, the relationship with metastasis was assessed only for the first (lilac) and second (green) gene groups (tabl. 2). In accordance with the working hypothesis, metastasis should be facilitated by amplification of gene loci of the first group and deletion of loci of genes of the second group, while inhibition of metastasis should be done by deletion of gene loci of the first group and amplification of loci of genes of the second group. In accordance with this formulation, a point system was developed. One point was added to the total score when amplifying WNT-signaling activators or deletion of negative regulators, and vice versa, when deleting WNT-signaling activators or amplification of negative regulators, one point was taken from the total amount. The distribution of amplifications and deletions at all loci of the genes of the first and second groups and the total score for all 30 patients studied are presented in Fig. 2. As seen in Fig. 2, $93 \%(14 / 15)$ of patients with metastases have a total score greater than 0 , while $93 \%(14 / 15)$ of patients without metastases have a total score of zero or less than zero. The differences between the groups are statistically significant according to the two-sided Fisher test with a high level of confidence probability $(p=0.000003)$ and the log-rank test $(p=0.00004)$ when assessing metastasis-free survival by the KaplanMayer method (fig. 3).

Thus, our data indicate that CNA genes of WNTsignaling are associated with metastasis and the prognostic value of CNA genes of WNT-signaling in residual tumors is highly predictive, which confirms our working hypothesis that CNA genes of WNT signaling are involved in the implementation of the metastasis process. Amplifications of stemness genes give tumor cells the ability to do stem transition [1], amplifications of activators $S K P 1, W N T 8 A, M A P K 9, C C N D 3, F Z D 9$,
WNT8B, CCND1, PLCB2, PRKCB, FZD2, WNT3, $W N T 9 B$ and / or deletions of negative regulators of WNT signaling genes: GSK3B, APC, CSNK2B, SFRP5, $B T R C, T C F 7 L 2, C S N K 2 A 2$, contribute to the release of tumor cells from replicative aging and dormant state, and activation of stem transition.

\section{Discussion}

The association of the combination of stemness gene amplifications and WNT-signaling genes in residual tumors with hematogenous metastasis was studied. Based on the microarray study and using bioinformatics methods, the most important WNT-signaling genes were identified for $12 \mathrm{WNT}$ signaling activator genes and 7 negative regulator genes, amplification and deletion (respectively) of which were associated with metastasis (according to the Fisher's two-sided criterion, $\mathrm{p}=0.000003$ and the log-rank test, $\mathrm{p}=0.00004$, when evaluated by the Kaplan-Mayer method).

According to modern recommendations, adjuvant chemotherapy $(\mathrm{ACH})$ is given to patients, who have not previously received 6-8 cycles of NACH. Current methods for predicting the risk of relapse (in particular, the Oncotype DX platform), which show the need for ACT are often inefficient, and even if they are used, the majority of patients (more than 40-50\% of patients) receive postoperative chemotherapy [8], while according to our data, only $25 \%$ of patients need adjuvant chemotherapy. These are patients with 2 or more amplifications of stemness genes and a positive total CNA score of WNT signaling genes. Our new prognostic factor is currently one of the most highly effective for breast cancer.

Some of the WNT signaling genes that we have identified are considered in the modern literature in terms of metastasis mechanisms. Gene FZD9 gene

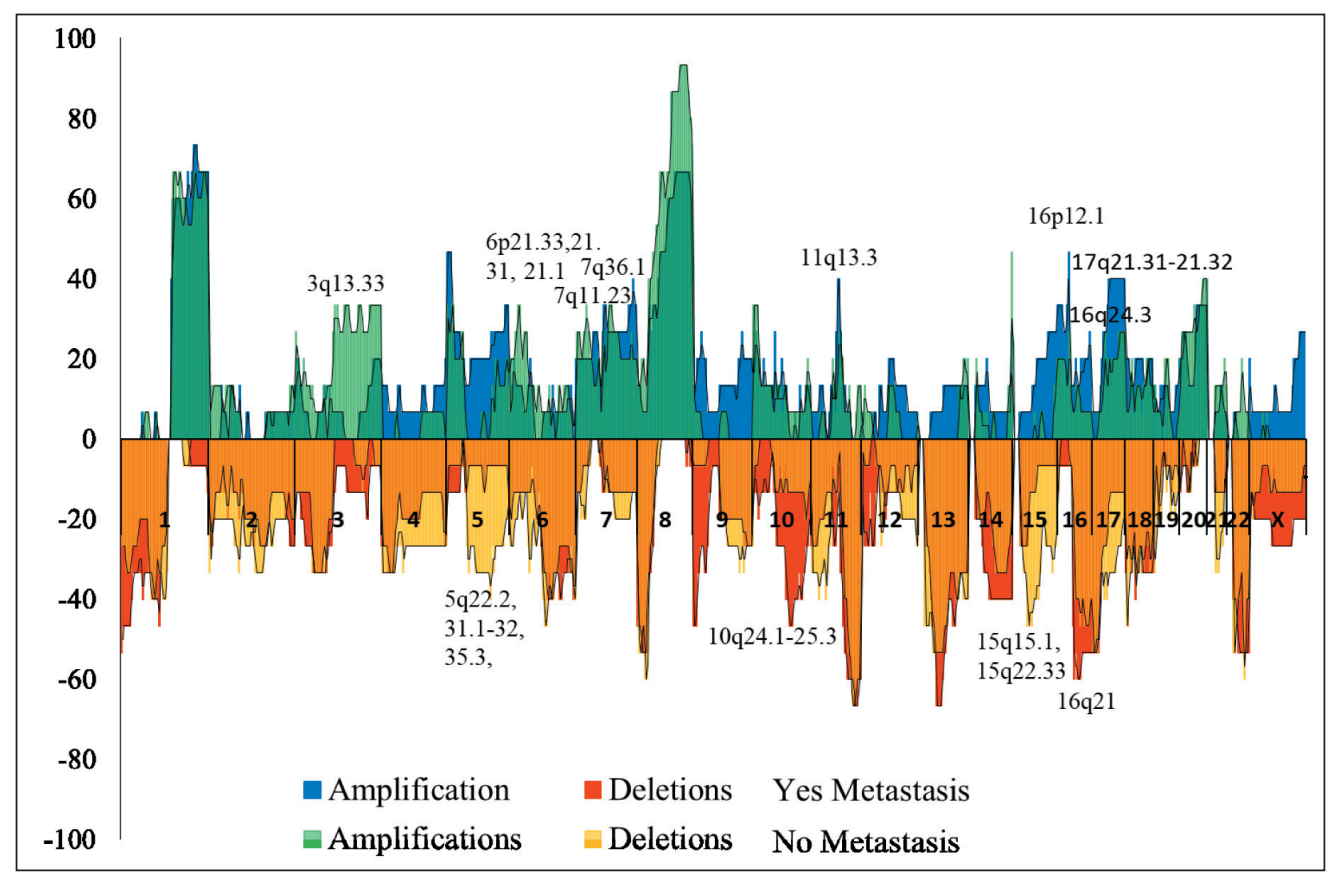

Рис. 1. Частота опухолевых CNA (амплификации и делеции) у пациенток с метастазами и без них

Fig. 1 Tumor CNA (amplifications and deletions) frequencies in patients with and without metastases 

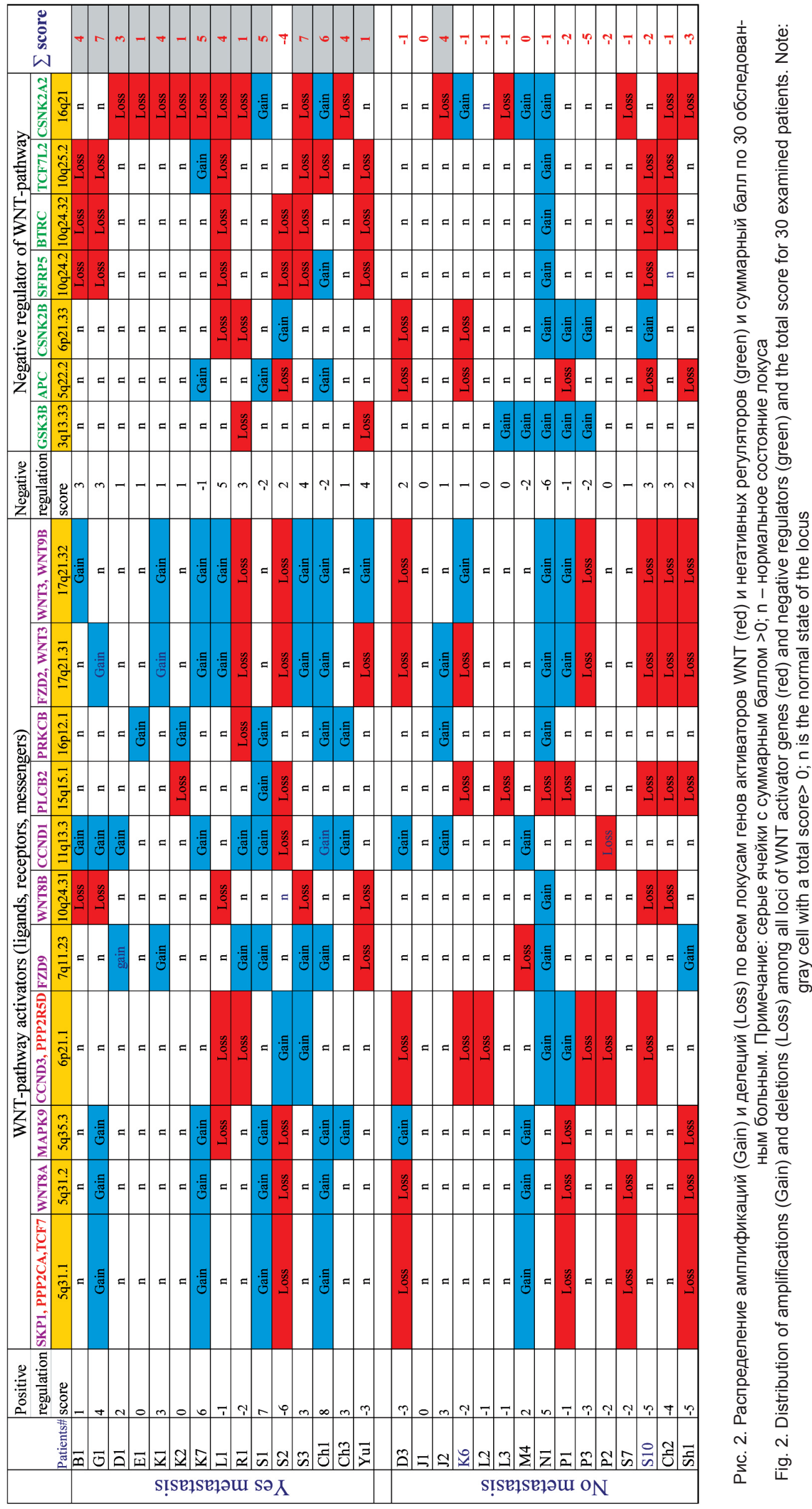


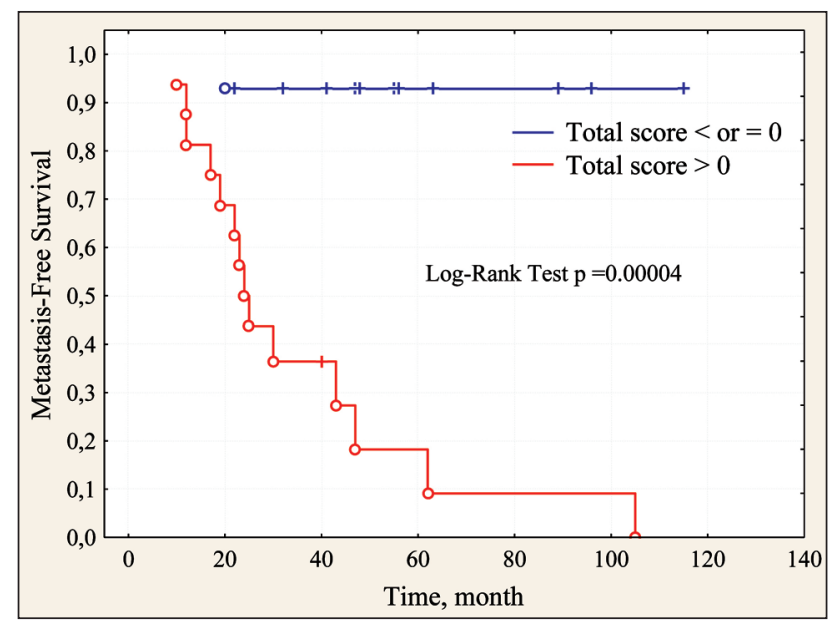

Рис. 3. Безметастатическая выживаемость больных раком молочной железы с 2 и более амплификациями генов стволовости в зависимости от суммарного балла по CNA генов WNT-pathway Fig. 3. Metastasis-free survival of patients with breast cancer with 2 or more amplifications of stemness genes depending on the total score on the CNA of the WNT pathway genes

is activated after exposure of breast tumor cells to chemotherapy and is involved in the induction of the stem phenotype in these cells [9]. Amplification of gene CCNDlgene is associated with a poor outcome in breast cancer [10]. Knockdown of CCND1 inhibits mammosphere formation of breast cancer cells [11]. MiR-4779 inhibits CCND3 in colon cancer cells, causing cell cycle arrest and apoptosis [12]. Inhibition of SKP1 leads to mitotic arrest of lung cancer cells [13]. Inhibitors of other activators of WNT signaling genes are being developed: PPP2CA [14], WNT3 [15] and others. For FZD2, on the contrary, it was shown that its hyperexpression was accompanied by suppression of metastasis of salivary adenoid cystic carcinomas [16]. Previous studies have shown that during EMT and metastasis, Wnt5a/b ligand and/or its cognate receptor Fzd2 are generally overexpressed in cell lines derived from late-stage mesenchymal-type cancers, such as melanoma and cancers of the, lung, colon, liver, and the gastric tract [17-19]. The WNT8A gene is associated with an unfavorable prognosis in patients with breast cancer treated with NAC [20].

As for negative regulators, there is much less information. The SNP of BTRC rs61873997 G>A gene

\section{ЛИTEPATYPA/REFERENCES}

1. Litviakov N., Ibragimova M., Tsyganov M., Kazantseva P., Deryusheva I., Pevzner A., Doroshenko A., Garbukov E., Tarabanovskaya N., Slonimskaya E. Amplifications of stemness genes and the capacity of breast tumors for metastasis. Oncotarget. 2020; 11: 1988-2001. doi: 10.18632/ oncotarget. 27608 .

2. Milanovic M. Fan D.N.Y., Belenki D., Däbritz J.H.M., Zhao Z. Yu Y., Dörr J.R., Dimitrova L., Lenze D., Monteiro Barbosa I.A., MendozaParra M.A., Kanashova T., Metzner M., Pardon K., Reimann M., Trumpp A., Dörken B., Zuber J., Gronemeyer H., Hummel M., Dittmar G., Lee S., Schmitt C.A. Senescence-associated reprogramming promotes cancer stemness. Nature. 2018 Jan 4; 553(7686): 96-100. doi: 10.1038/nature25167.

3. Zhan T., Rindtorff N., Boutros M. Wnt signaling in cancer. Oncogene. 2017 Mar; 36(11): 1461-1473. doi: 10.1038/onc.2016.304.

4. Acebron S.P., Karaulanov E., Berger B.S., Huang Y.-L., Niehrs C. Mitotic wnt signaling promotes protein stabilization and regulates cell size. Molecular cell. 2014; 54(4): 663-74. doi.org/10.1016/j.molcel.2014.04.014 was associated with the prognosis for skin cancer, and the presence of the wild allele had an unfavorable effect with $\mathrm{HR}=0.61(0.46-0.80), \mathrm{p}=0.00031)$ [21]. Suppression of negative WNT regulators does not always lead to inhibition of metastasis. In some cases, WNT activation inhibits metastasis. Thus, it was shown that pharmacological inhibition of GSK $3 B$ activity stabilized the TRAF6 protein, promoted $C T N N B 1$ degradation, and effectively suppressed EMT and CRC metastasis [22]. On the other hand, tamoxifen treatment of breast cancer cells increases the phosphorylation of $G S K 3 B$ and, therefore, its activity [23]. Low expression of SFRP5 in human pancreatic ductal adenocarcinoma (PDAC) was a poor prognostic factor for human PDAC [24]. Epigenetic inactivation of the SFRP5 gene in human breast cancer is associated with unfavorable prognosis [25]. The $A P C$ gene is a known tumor suppressor gene and in breast cancer its deletion is associated with resistance to doxorubicin and cisplatin $[26,27]$.

The indirect effect of negative regulators should also not be neglected. It is well known that TP53 and $C D K N 2 A$ genes are considered the main barrier to efficient conversion of normal cells into induced pluripotent stem cells. They inhibit spontaneous transformation of differentiated cells into pluripotent ones [28]. Some negative regulators are able to activate TP53 [3]. Apparently, deletions of these genes lead to a decrease in TP53 activity and, as a result, thresholds for transition of differentiated tumor cells to tumor stem cells are reduced. This may be one of the explanations of the effect observed by Milanovic [2] which consists in a sharp increase in the number of tumor stem cells upon activation of WNT signaling after cancellation of chemo and hormonal therapy.

\section{Conclusion}

The results of the study confirm the working hypothesis that CNAs of WNT signaling genes are involved in the metastatic process. Nineteen WNT signaling genes were identified. Copy number aberrations of these genes in combination with stemness gene amplifications in residual tumors were found to be associated with metastasis. A new highly effective prognostic factor for breast cancer was developed.

5. Kaveri D., Kastner P., Dembélé D., Nerlov C., Chan S., Kirstetter P. $\beta$-Catenin activation synergizes with Pten loss and Myc overexpression in Notch-independent T-ALL. Blood. 2013 Aug 1; 122(5): 694-704. doi: 10.1182/blood-2012-12-471904.

6. Wolff A.C., Hammond M.E., Hicks D.G., Dowsett M., McShane L.M., Allison K.H., Allred D.C., Bartlett J.M., Bilous M., Fitzgibbons P., Hanna W., Jenkins R.B., Mangu P.B., Paik S., Perez E.A., Press M.F., Spears P.A., Vance G.H., Viale G., Hayes D.F.; American Society of Clinical Oncology; College of American Pathologists. Recommendations for human epidermal growth factor receptor 2 testing in breast cancer: American Society of Clinical Oncology/College of American Pathologists clinical practice guideline update. J Clin Oncol. 2013 Nov 1; 31(31): 3997-4013. doi: 10.1200/JCO.2013.50.9984.

7. Hayward J.L., Carbone P.P., Heusen J.C., Kumaoka S., Segaloff A., Rubens R.D. Assessment of response to therapy in advanced breast cancer. Br J Cancer. 1977 Mar; 35(3): 292-8. doi: 10.1038/bjc.1977.42.

8. Dodson A., Okonji D., Assersohn L., Rigg A., Sheri A., Turner N., Smith I., Parton M., Dowsett M. Discordance between oncotype DX 
recurrence score and RSPC for predicting residual risk of recurrence in ER-positive breast cancer. Breast Cancer Research and Treatment. 2018; 168(1): 249-58. doi: 10.1007/s10549-017-4514-z.

9. Tudoran O., Soritau O., Balacescu L., Visan S., Barbos O., Cojocneanu-Petric R., Balacescu O., Berindan-Neagoe I. Regulation of stem cells-related signaling pathways in response to doxorubicin treatment in Hs578T triple-negative breast cancer cells. Mol Cell Biochem. 2015 Nov; 409(1-2): 163-76. doi: 10.1007/s11010-015-2522-z.

10. Roy P.G., Thompson A.M. Cyclin D1 and breast cancer. Breast. 2006 Dec; 15(6): 718-27. doi: 10.1016/j.breast.2006.02.005.

11. Adorno-Cruz V., Hoffmann A.D., Liu X., Dashzeveg N.K., Taftaf R., Wray B., Liu H. ITGA2 promotes expression of ACLY and CCND1 in enhancing breast cancer stemness and metastasis. Genes \& Diseases. 2020. doi: doi: 10.1016/j.gendis.2020.01.015.

12. Koo K.H., Kwon H. MicroRNA miR-4779 suppresses tumor growth by inducing apoptosis and cell cycle arrest through direct targeting of PAK2 and CCND3. Cell Death Dis. 2018; 9(2): 77. doi: 10.1038 s41419-017-0100-x.

13. Liu Y.Q., Wang X.L., Cheng X., Lu Y.Z., Wang G.Z., Li X.C., Zhang J., Wen Z.S., Huang Z.L., Gao Q.L., Yang L.N., Cheng Y.X., Tao S.C., Liu J., Zhou G.B. Skp1 in lung cancer: clinical significance and therapeutic efficacy of its small molecule inhibitors. Oncotarget. 2015; 6(33): 34953-67. doi: 10.18632/oncotarget.5547.

14. D'Arcy B.M., Swingle M.R., Papke C.M., Abney K.A., Bouska E.S., Prakash A., Honkanen R.E. The Antitumor Drug LB-100 Is a Catalytic Inhibitor of Protein Phosphatase 2A (PPP2CA) and 5 (PPP5C) Coordinating with the Active-Site Catalytic Metals in PPP5C. Mol Cancer Ther. 2019 Mar; 18(3): 556-566. doi: 10.1158/1535-7163.MCT-17-1143.

15. Wu Y., Tran T., Dwabe S., Sarkissyan M., Kim J., Nava M., Clayton S., Pietras R., Farias-Eisner R., Vadgama J.V. A83-01 inhibits TGF- $\beta$-induced upregulation of Wnt3 and epithelial to mesenchymal transition in HER2-overexpressing breast cancer cells. Breast Cancer Res Treat. 2017 Jun; 163(3): 449-460. doi: 10.1007/s10549-017-4211-y.

16. Ding L.C., Huang X.Y., Zheng F.F., Xie J., She L., Feng Y., Su B.H., Zheng D.L., Lu Y.G. FZD2 inhibits the cell growth and migration of salivary adenoid cystic carcinomas. Oncol Rep. 2016; 35(2): 1006-12. doi: 10.3892/or.2015.3811.

17. Zhang Y., Du J., Zheng J., Liu J., Xu R., Shen T., Zhu Y., Chang J., Wang H., Zhang Z., Meng F., Wang Y., Chen Y., Xu Y., Gu L. EGF-reduced Wnt5a transcription induces epithelial-mesenchymal transition via Arf6ERK signaling in gastric cancer cells. Oncotarget. 2015 Mar 30; 6(9): 7244-61. doi: 10.18632/oncotarget.3133.

18. Yamamoto H., Oue N., Sato A., Hasegawa Y., Yamamoto H., Matsubara A., Yasui W., Kikuchi A. Wnt5a signaling is involved in the aggressiveness of prostate cancer and expression of metalloproteinase. Oncogene. 2010 Apr 8; 29(14): 2036-46. doi: 10.1038/onc.2009.496.
19. Gujral T.S., Chan M., Peshkin L., Sorger P.K., Kirschner M.W., MacBeath $G$. A noncanonical Frizzled2 pathway regulates epithelialmesenchymal transition and metastasis. Cell. 2014; 159(4): 844-56. doi: 10.1016/j.cell.2014.10.032

20. Wong A.L.A., Tan K.T., Sundar R., Ow S., Pang A., Yap H-L., Chan C-W. Hartman M. Iau P., Buhari S.A. Genomic predictors of neoadjuvant chemotherapy (NACT) response in breast cancer (BC). J Clin Oncol. 2017; 35: 15_suppl. doi: 10.1200/JCO.2017.35.15_suppl.e12122.

21. Shi $\bar{Q}$., Liu H., Han P., Li C., Wang Y., Wu W., Zhu D., Amos C.I., Fang S., Lee J.E., Han J., Wei Q. Genetic Variants in WNT2B and BTRC Predict Melanoma Survival. J Invest Dermatol. 2017; 137(8): 1749-56. doi: $10.1016 /$ j.jid.2017.04.023.

22. Wu H., Lu X.X.,Wang J.R., Yang T.Y, Li X.M. He X.S. Li Y. Ye W.L., Wu Y., Gan W.J., Guo P.D., Li J.M. TRAF6 inhibits colorectal cancer metastasis through regulating selective autophagic CTNNB1/ $\beta$ catenin degradation and is targeted for GSK3B/GSK3 3 -mediated phosphorylation and degradation. Autophagy. 2019 Sep; 15(9): 1506-22. doi: 10.1080/15548627.2019.1586250.

23. Chen I.C., Hsiao L.P., Huang I.W., Yu H.C., Yeh L.C., Lin C.H., Wei-Wu Chen T. Cheng A.L., Lu Y.S. Phosphatidylinositol-3 Kinase Inhibitors, Buparlisib and Alpelisib, Sensitize Estrogen Receptor-positive Breast Cancer Cells to Tamoxifen. Sci Rep. 2017; 7(1): 9842. doi: 10.1038/ s41598-017-10555-z.

24. Zhou W., Tian M., Hu J., Li L., He Y. SFRP5 as a prognostic biomarker for patients with pancreatic ductal adenocarcinoma. Int J Clin Exp Pathol. 2016; 9(3): 3442-3447.

25. VeeckJ., Geisler C., Noetzel E., Alkaya S., Hartmann A., Knüchel R., $D a h l E$. Epigenetic inactivation of the secreted frizzled-related protein-5 (SFRP5) gene in human breast cancer is associated with unfavorable prognosis. Carcinogenesis. 2008 May; 29(5): 991-8. doi: 10.1093/carcin/ bgn076.

26. Van Klompenberg M.K., Leyden E., Arnason A.H., Zhang J.T., Stefanski C.D., Prosperi J.R. APC loss in breast cancer leads to doxorubicin resistance via STAT3 activation. Oncotarget. 2017; 8(61): 102868-79. doi: 10.18632/oncotarget.22263.

27. Stefanski C.D., Keffler K., McClintock S., Milac L., Prosperi J.R. APC loss affects DNA damage repair causing doxorubicin resistance in breast cancer cells. Neoplasia. 2019; 21(12): 1143-50. doi.org/10.1016/j. neo.2019.09.002

28. Onder T.T. Kara N., Cherry A., Sinha A.U., Zhu N., Bernt K.M., Cahan P., Marcarci B.O., Unternaehrer J., Gupta P.B., Lander E.S., Armstrong S.A., Daley G.Q. Chromatin-modifying enzymes as modulators of reprogramming. Nature. 2012 Mar 4; 483(7391): 598-602. doi: 10.1038/nature10953.

Поступила/Received 03.02.2020 Принята в печать/Accepted 30.05.2020

\section{СВЕДЕНИЯ ОБ АВТОРАХ}

Литвяков Николай Васильевич, доктор биологических наук, заведующий лабораторией онковирусологии, Научноисследовательский институт онкологии, Томский национальный исследовательский медицинский центр Российской академии наук (г. Томск, Россия). SPIN-код: 2546-0181. AuthorID (РИНЦ): 183820. Researcher ID (WOS): C-3263-2012. ORCID: 0000-00020714-8927. Author ID (Scopus): 6506850698.

Ибрагимова Марина Константиновна, младший научный сотрудник лаборатории онковирусологии, Научно-исследовательский институт онкологии, Томский национальный исследовательский медицинский центр Российской академии наук (г. Томск, Россия). SPIN-код: 2340-1628. Researcher ID (WOS): C-8609-2012. Author ID (Scopus): 57130579200. ORCID: 0000-0001-8815-2786.

Цыганов Матвей Михайлович, кандидат биологических наук, научный сотрудник лаборатории онковирусологии, Научноисследовательский институт онкологии, Томский национальный исследовательский медицинский центр Российской академии наук (г. Томск, Россия). SPIN-код: 1253-0240. Researcher ID (WOS): A-7212-2014. Author ID (Scopus): 55366377400. ORCID: 0000-0001-7419-4512.

Дерюшева Ирина Валерьевна, младший научный сотрудник лаборатории онковирусологии, Научно-исследовательский институт онкологии, Томский национальный исследовательский медицинский центр Российской академии наук (г. Томск, Россия). SPIN-код: 5560-6131. AuthorID (РИНЦ): 881749. Researcher ID (WOS): Q-5607-2017. Author ID (Scopus): 57194535404. ORCID: 0000-0002-9568-3371.

Певзнер Алина Михайловна, лаборант-исследователь лаборатории онковирусологии, Научно-исследовательский институт онкологии, Томский национальный исследовательский медицинский центр Российской академии наук (г. Томск, Россия). SPINкод: 3847-352. Researcher ID (WOS): AAD-2192-2019. Author ID (Scopus): 57209511993. ORCID: 0000-0002-9657-9058

Гарбуков Евгений Юрьевич, кандидат медицинских наук, старший научный сотрудник отделения общей онкологии, Научноисследовательский институт онкологии, Томский национальный исследовательский медицинский центр Российской академии наук (г. Томск, Россия). SPIN-код: 3630-2324. AuthorID (РИНЦ): 557911. Researcher ID (WOS): C-8299-2012. Author ID (Scopus): 6504255124.ORCID: 0000-0002-2917-8158.

Дорошенко Артем Васильевич, кандидат медицинских наук, научный сотрудник отделения общей онкологии, Научноисследовательский институт онкологии, Томский национальный исследовательский медицинский центр Российской академии наук (г. Томск, Россия). SPIN-код: 7874-7606. AuthorID (РИНЦ): 214813. Researcher ID (WOS): D-2348-2012. Author ID (Scopus): 7402005343. ORCID: 0000-0001-8846-9636. 
Слонимская Елена Михайловна, доктор медицинских наук, профессор, Санкт-Петербургский государственный университет (г. Санкт-Петербург, Россия). SPIN-код: 7763-6417. Researcher ID (WOS): C-7405-2012. Author ID (Scopus): 6603658443. ORCID: 0000-0003-4382-5697.

\section{ВКЛАД АВТОРОВ}

Литвяков Николай Васильевич: анализ научной работы, написание статьи.

Ибрагимова Марина Константиновна: сбор и интерпретация данных.

Цыганов Матвей Михайлович: сбор и интерпретация данных.

Дерюшева Ирина Валерьевна: сбор и интерпретация данных, формирование базы данных.

Певзнер Алина Михайловна: сбор и интерпретация данных, формирование базы данных.

Гарбуков Евгений Юрьевич: подбор и обработка клинического материала.

Дорошенко Артем Васильевич: подбор и обработка клинического материала.

Слонимская Елена Михайловна: общее руководство, критическая редакция с внесением важного интеллектуального содержания.

\section{Финансирование}

Работа выполнена при финансовой поддержке гранта РФФИ№ 18-29-09131 «Феномен «замирания» опухоли в процессе химиотерапии».

\section{Конфликт интересов}

Авторы объявляют, что у них нет конфликта интересов.

\section{ABOUT THE AUTHORS}

Nikolai V. Litviakov, DSc, Head of Laboratory of Viral Oncology, Cancer Research Institute, Tomsk National Research Medical Center, Russian Academy of Sciences (Tomsk, Russia). E-mail: nvlitv72@yandex.ru. Researcher ID (WOS): C-3263-2012. ORCID: 0000-0002-0714-8927. Author ID (Scopus): 6506850698

Marina K. Ibragimova, Junior Researcher, Laboratory of Viral Oncology, Cancer Research Institute, Tomsk National Research Medical Center, Russian Academy of Sciences (Tomsk, Russia). Researcher ID (WOS): C-8609-2012. Author ID (Scopus): 57130579200. ORCID: 0000-0001-8815-2786.

Matvey M. Tsyganov, PhD, Researcher, Laboratory of Viral Oncology, Cancer Research Institute, Tomsk National Research Medical Center, Russian Academy of Sciences (Tomsk, Russia). Researcher ID (WOS): A-7212-2014. Author ID (Scopus): 55366377400. ORCID: 0000-0001-7419-4512.

Irina V. Deriusheva, Junior Researcher, Laboratory of Viral Oncology, Cancer Research Institute, Tomsk National Research Medical Center, Russian Academy of Sciences (Tomsk, Russia). Researcher ID (WOS): Q-5607-2017. Author ID (Scopus): 57194535404. ORCID: 0000-0002-9568-3371.

Alina M. Pevsner, Junior Researcher, Laboratory of Viral Oncology, Cancer Research Institute, Tomsk National Research Medical Center, Russian Academy of Sciences (Tomsk, Russia). Researcher ID (WOS): AAD-2192-2019. Author ID (Scopus): 57209511993. ORCID: 0000-0002-9657-9058.

Eugeniy Yu. Garbukov, MD, PhD, Senior Researcher, Department of General Oncology, Cancer Research Institute, Tomsk National Research Medical Center, Russian Academy of Sciences (Tomsk, Russia). Researcher ID (WOS): C-8299-2012. Author ID (Scopus): 6504255124.ORCID: 0000-0002-2917-8158.

Artem V. Doroshenko, MD, PhD, Researcher, Department of General Oncology, Cancer Research Institute, Tomsk National Research Medical Center, Russian Academy of Sciences (Tomsk, Russia). Researcher ID (WOS): D-2348-2012. Author ID (Scopus): 7402005343. ORCID: 0000-0001-8846-9636.

Elena M. Slonimskaya, MD, DSc, Professor, Saint-Petersburg State University (Saint-Petersburg, Russia). Researcher ID (WOS): C-7405-2012. Author ID (Scopus): 6603658443. ORCID: 0000-0003-4382-5697.

\section{AUTHOR CONTRIBUTION}

Nikolai V. Litviakov: analysis of scientific work, writing the manuscript.

Marina K. Ibragimova: data collection and analysis.

Matvey M. Tsyganov: data collection and analysis.

Irina V. Deriusheva: data collection and analysis, database formation.

Alina M. Pevsner: data collection and analysis, database formation.

Eugeniy Yu. Garbukov: selection of clinical material.

Artem V. Doroshenko: selection of clinical material.

Elena M. Slonimskaya: management, critical revision for the important intellectual content.

\section{Funding}

This study was carried out with the financial support of the grant of the Russian Foundation for Basic Research № 18-29-09131 «The phenomenon of tumor «fading» during chemotherapy».

Conflict of interest

The authors declare that they have no conflict of interest. 